NBER WORKING PAPER SERIES

THE EFFECT OF JOINT AND SEVERAL LIABILITY UNDER SUPERFUND ON BROWNFIELDS

Howard F. Chang

Hilary Sigman

Working Paper 11667

http://www.nber.org/papers/w11667

\author{
NATIONAL BUREAU OF ECONOMIC RESEARCH \\ 1050 Massachusetts Avenue \\ Cambridge, MA 02138 \\ October 2005
}

Professor of Law, University of Pennsylvania Law School, and Associate Professor of Economics, Rutgers University, respectively. Copyright (C) 2005 by Howard F. Chang and Hilary Sigman. We developed this paper under STAR Research Assistance Agreement No. R831777, awarded by the U.S. Environmental Protection Agency (EPA), but the EPA has not formally reviewed this paper. The views expressed in this document are those of the authors, and the EPA does not endorse any products or commercial services mentioned in this paper. The views expressed herein are those of the author(s) and do not necessarily reflect the views of the National Bureau of Economic Research.

(C) 2005 by Howard F. Chang and Hilary Sigman. All rights reserved. Short sections of text, not to exceed two paragraphs, may be quoted without explicit permission provided that full credit, including (C) notice, is given to the source. 
The Effect of Joint and Several Liability Under Superfund on Brownfields

Howard F. Chang and Hilary Sigman

NBER Working Paper No. 11667

October 2005

JEL No. Q5,K32,R3

\begin{abstract}
$\underline{\text { ABSTRACT }}$
In response to claims that the threat of environmental liability under the Superfund law deters the acquisition of potentially contaminated sites (or "brownfields") for redevelopment, the federal government has adopted programs to protect purchasers from liability. This protection may be unwarranted, however, if sellers can simply adjust property prices downward to compensate buyers for this liability. We present a model of joint and several liability under Superfund that allows us to distinguish four different reasons that this liability may discourage the purchase of brownfields. The previous literature has overlooked the effects that we identify, which all arise because a sale may increase the number of defendants in a suit to recover cleanup costs. Our analysis suggests that the brownfields problem may be more widespread than one might infer from the prior literature. Furthermore, the effects that we identify may distort not only the incentives to sell property subject to Superfund liability but also any decision of any party subject to any joint and several liability if that decision could affect the number of other defendants liable for the same harm.
\end{abstract}

Howard F. Chang

200 Stuart Rd. East

Princeton, NJ 08540-1946

hchang@law.upenn.edu

Hilary Sigman

Department of Economics

Rutgers University

75 Hamilton Street

New Brunswick, NJ 08901-1248

and NBER

sigman@econ.rutgers.edu 
CONTENTS

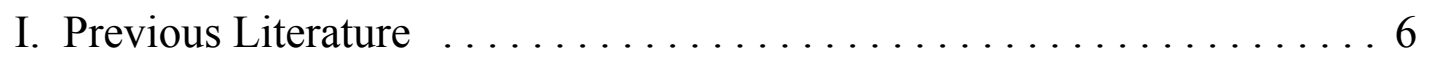

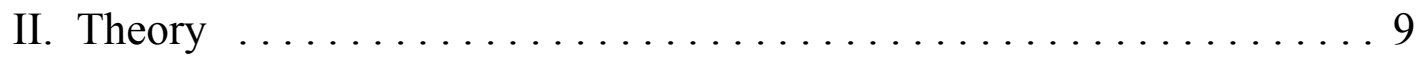

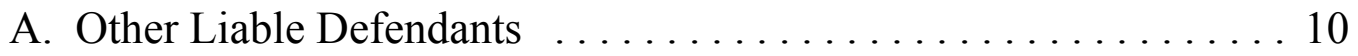

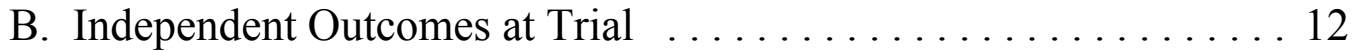

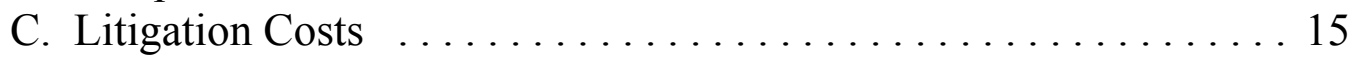

D. Settlements ............................. 18

1. Correlated Outcomes at Trial ................. 19

a. Two Defendants and Zero Litigation Costs . ......... 19

b. Other Defendants and Litigation Costs ............ 23

2. Independent Outcomes at Trial ................ 26

3. Implications for the General Case . . . . . . . . . . . . 29

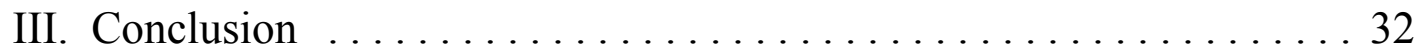




\title{
THE EFFECT OF JOINT AND SEVERAL LIABILITY UNDER SUPERFUND ON BROWNFIELDS
}

\author{
HOWARD F. CHANG and HILARY SIGMAN*
}

The Comprehensive Environmental Response, Compensation, and Liability Act (CERCLA), ${ }^{1}$ also known as the federal Superfund statute, makes certain specified parties potentially responsible for the costs of cleaning up a contaminated site. These potentially responsible parties (PRPs) may include the current owners of such a site, generators and transporters of hazardous waste, and certain prior owners of the site. ${ }^{2}$ Courts have interpreted CERCLA to impose joint and several liability on these PRPs for any indivisible harm caused by hazardous substances at the site. ${ }^{3}$ Joint and several liability allows the government to recover the full costs of cleanup at the site from any PRP, regardless of the PRP's equitable share of the liability.

Many commercial real estate developers and observers claim that the threat of Superfund liability deters the acquisition of potentially contaminated sites for redevelopment. This claim has stirred concerns about "brownfield" sites,

\footnotetext{
* Earle Hepburn Professor of Law, University of Pennsylvania Law School, and Associate Professor of Economics, Rutgers University, respectively. Copyright (C) 2007 by Howard F. Chang and Hilary Sigman. We wish to thank Lucian Bebchuk, David Gilo, Jason Johnston, Daniel Klerman, Richard Revesz, and conference participants at the 2007 meeting of the American Law and Economics Association and the 2006 meetings of the European Association of Law and Economics, of the World Congress of Environmental and Resource Economists, of the Canadian Law and Economics Association, and on Game Theory and Practice Dedicated to Development, Natural Resources, and the Environment, and workshop participants at Tel Aviv University, Bar-Ilan University, and Drexel University for helpful comments. We developed this paper under STAR Research Assistance Agreement No. R831777, awarded by the U.S. Environmental Protection Agency (EPA), but the EPA has not formally reviewed this paper. The views expressed in this document are those of the authors, and the EPA does not endorse any products or commercial services mentioned in this paper.

${ }^{1} 42$ U.S.C. $\S \S 9601-75(2000)$.

${ }^{2}$ See $i d . \S 9607(\mathrm{a})$.

${ }^{3}$ See, e.g., United States v. Alcan Aluminum Corp., 964 F.2d 252, 268-69 (3d Cir. 1992); O’Neil v. Picillo, 883 F.2d 176, 178-79 ( $1^{\text {st }}$ Cir. 1989), cert. denied, 493 U.S. 1071 (1990); United States v. Monsanto Co., 858 F.2d 160, 171-73 ( $4^{\text {th }}$ Cir. 1988), cert. denied, 490 U.S. 1106 (1989); United States v. Bliss, 667 F. Supp. 1298, 1312-13 (E.D. Mo. 1987); United States v. Ottati \& Goss, Inc., 630 F. Supp. 1361, 1395-96 (D.N.H. 1985); United States v. Chem-Dyne Corp., 572 F. Supp. 802, 810-11 (S.D. Ohio 1983).
} 
which CERCLA defines as "real property, the expansion, redevelopment, or reuse of which may be complicated by the presence or potential presence of a hazardous substance, pollutant, or contaminant." encourage the redevelopment of these "brownfields" because these sites are considered not only sources of urban blight but also substitutes for the introduction of new industrial sites in suburban rural locations, sometimes known as "greenfields." The use of greenfields would reduce open space, contribute to suburban sprawl, and require construction of new infrastructure.

A U.S. Conference of Mayors (USCM) survey found 95,000 acres of brownfields in 192 responding cities. ${ }^{5}$ The USCM survey respondents listed "liability issues" as second only to "lack of clean up funds" as an obstacle to the redevelopment of these sites. ${ }^{6}$ Similarly, a recent survey of private developers indicated that they consider protection from liability for cleanup costs to be a valuable incentive to buy and to develop contaminated sites. ${ }^{7}$

Responding to the problem of brownfields, the U.S. Environmental Protection Agency (EPA), local communities, and developers have explored various ways to encourage the redevelopment of these sites. ${ }^{8}$ In 1995, the EPA announced that it would issue more "comfort letters" to assure owners engaged in cleanups that the EPA would not subject their properties to further

\footnotetext{
${ }^{4} 42$ U.S.C.A. § 9601(39)(A) (West Supp. 2005).
}

${ }^{5}$ See 4 U.S. Conference of Mayors, Recycling America's Land: A National Report on Brownfields Redevelopment 12 (2003).

${ }^{6}$ See $i d$. at 14 .

${ }^{7}$ See Kris Wernstedt, et al., The Brownfields Phenomenon: Much Ado about Something or the Timing of the Shrewd? 17 (Resources for the Future Discussion Paper No. 04-46, 2004); Kris Wernstedt, Peter B. Meyer \& Anna Alberini, Attracting Private Investment to Contaminated Properties: The Value of Public Interventions, 25 J. Pol'y Analysis \& Mgmt. 347,361 (2006).

8 "Brownfields," according to the EPA definition, "are abandoned, idled, or under-used industrial and commercial facilities where expansion or redevelopment is complicated by real or perceived environmental contamination." Office of Enforcement \& Compliance Assurance, U.S. Envtl. Protection Agency, Policy Toward Owners of Property Containing Contaminated Aquifers 1 (1995). 
CERCLA actions. ${ }^{9}$ As part of its brownfields initiative, the EPA also sought to expand the use of "prospective purchaser agreements," whereby a prospective purchaser and the EPA enter a binding contract that includes a "covenant not to sue" the prospective purchaser under CERCLA. ${ }^{10}$ Under such an agreement, the government agrees not to sue the purchaser for any existing contamination in exchange for "adequate consideration," such as reimbursement of cleanup costs or the performance of specified cleanup work by the prospective purchaser. ${ }^{11}$ The EPA announced that it would consider such agreements if they would provide a "substantial" benefit, including "a payment for cleanup or a commitment to perform a response action" or benefits to the local community "through the creation or retention of jobs, productive use of abandoned property, or revitalization of blighted areas." 12

In 2002, the Small Business Liability Relief and Brownfields Revitalization $\mathrm{Act}^{13}$ amended the Superfund law to exempt a "bona fide prospective purchaser" from liability as an "owner" under CERCLA as long as the purchaser "does not impede the performance of a response action or natural resource restoration" at the site. ${ }^{14}$ Purchasers are exempt from this liability if they meet certain specified conditions. The definition of "bona fide prospective purchaser," for example, requires the purchaser to show that all disposal of hazardous substances at the site took place before the purchaser acquired the property, to undertake "all appropriate inquiries" to discover any contamination, to exercise "appropriate care" with respect to hazardous substances found at the site by taking "reasonable steps" to stop any continuing release of those substances and to prevent any future release, and to

\footnotetext{
${ }^{9}$ Robert V. Percival, et al., Environmental Regulation: Law, Science, and Policy 269 ( $4^{\text {th }}$ ed. 2003); Zygmunt J.B. Plater et al., Environmental Law and Policy 1018 (3d ed. 2004); Timothy Noah, EPA Plans Rules to Limit Liability of Superfund Sites, Wall St. J., Jan. 26, 1995, at A5.

${ }^{10}$ Announcement and Publication of Guidance on Agreements with Prospective Purchasers of Contaminated Property and Model Prospective Purchaser Agreement, 60 Fed. Reg. 34,792 (1995).

${ }^{11}$ Id. at 34,794 .

${ }^{12} I d$. at $34,792-93$.

${ }^{13}$ Pub. L. No. 107-118, 115 Stat. 2356 (2002).

${ }^{14} 42$ U.S.C.A. $§ 9607(r)$ (West Supp. 2005).
} 
provide "full cooperation" with the government or other persons conducting "response actions." 15 The legislation also creates a program of federal grants to states and local communities for "assessment," "remediation," and "revitalization" of brownfields. ${ }^{16}$ Despite all these measures, some critics remain dissatisfied with Superfund liability. ${ }^{17}$

Moreover, each state has its own laws governing the cleanup of contaminated sites in addition to the federal Superfund law. Many state rules mimic the CERCLA liability provisions, including joint and several liability for owners and a broad set of other parties, but some states use different rules. $^{18}$ Most states also have their own brownfields programs, which offer various incentives for prospective purchasers and developers, including "comfort" or "no further action" letters and covenants not to sue. ${ }^{19}$

Similarly, joint and several liability is both common and controversial in the environmental laws of other countries. Most members of the European Union (EU) and other members of the Organization for Economic Cooperation and Development (OECD), for example, rely on joint and several environmental liability to some extent but have increasingly limited its scope. ${ }^{20}$ Thus, an analysis of the effects of the federal Superfund regime in the United States provides not only the basis for an evaluation that regime but also some guidance for both states and other countries considering whether to adopt laws and policies similar to those adopted by the U.S. government.

${ }^{15} I d . \S 9601(40)$.

${ }^{16} I d . \S 9604(\mathrm{k})$.

${ }^{17}$ See Mark Reisch, Resources, Science \& Indus. Div., Congressional Research Serv., Brownfields and Superfund Issues in the $108^{\text {th }}$ Congress (2004).

${ }^{18}$ See Environmental Law Inst., An Analysis of State Superfund Programs: 50-State Study, 2001 Update 32-33 (2002); Elizabeth Glass Geltman, Recycling Land: Encouraging the Redevelopment of Contaminated Property, Nat. Resources \& Env't, Spring 1996, at 3, 4-5.

${ }^{19}$ Geltman, supra note 18, at 9; see Environmental Law Inst., supra note 18, at 41-43; Plater et al., supra note 9, at 1019-20; Charles Bartsch \& Rachel Deane, Brownfields State of the States: An End-of-Session Review of Initiatives and Program Impacts in the 50 States $\left(5^{\text {th }}\right.$ ed. 2002).

${ }^{20}$ See Chris Clarke, Update Comparative Legal Study on Environmental Liability (2001). 
Superfund liability may well inhibit the development of contaminated property by discouraging buyers from purchasing these sites, but the reasons for such an effect are more subtle than they might first appear. After all, if the liability rules merely forced the buyer to accept some share of a fixed expected liability that they would otherwise impose on the seller, then they would not deter a developer from buying the property as long as that transaction would efficiently transfer the property to the party that would produce greater value from the property. The parties would simply adjust the price of the property downward to reflect the transfer of liability from seller to buyer, and this discount would ensure that economically efficient transactions go forward in spite of this transfer of liability.

In Section I of this paper, we survey theories proposed in the previous economic literature suggesting how environmental liability may discourage the redevelopment of contaminated sites despite the tendency for land prices to compensate buyers for the liabilities associated with the property. In Section II of this paper, we present a formal model of joint and several liability under Superfund and advance four different reasons for this Superfund liability to discourage the purchase of contaminated property. The previous literature has overlooked the four effects that we identify, which all arise because the purchase may increase the number of defendants in a suit to recover cleanup costs. First, a sale may increase the share of liability that a seller and a buyer may expect to pay as a group. Second, a sale may increase the amount of damages that the government can expect to recover from the PRPs at trial. Third, a sale may increase the total litigation costs that a buyer and a seller may face as a group. Fourth, a sale may increase the amount that the government can expect to extract from PRPs in a settlement. Our analysis suggests that the brownfields problem may be more widespread than one might infer from the prior literature. Furthermore, the effects that we identify may distort not only the decision to sell property subject to Superfund liability but also any other decision of any PRP that could affect the number of PRPs at the site, for example, a generator's decision whether to transport its own wastes or to have an independent firm transport those wastes. Indeed, the distortions that we identify may affect any decision by any party subject to any regime of joint and several liability if that decision could affect the number of other defendants liable for the same harm. In Section III of this paper, we conclude with a discussion of the implications of our analysis for law and public policy. 


\section{Previous Literature}

Economists have recognized that land prices may include discounts reflecting environmental liability for cleanup of contaminated property. Thus, this liability need not affect the incentives for developers to buy these sites. The previous economic literature identifies some possible reasons that a transfer of liability to a party buying contaminated property may nevertheless discourage efficient transactions.

First, Kathleen Segerson (1993) notes that if the buyer and the seller are not equally likely to be judgment-proof, then a transfer of liability would distort incentives to transfer the property from buyer to seller. ${ }^{21}$ Liability would create too great an incentive to transfer the property to prospective buyers that are more likely to be judgment-proof than the current owner and too little incentive to transfer the property to prospective buyers that are less likely to be judgment-proof than the current owner. If the prospective buyer is less likely to be judgment-proof than the current owner, then the proposed sale would impose a greater expected liability cost on the buyer than the reduction in the expected liability cost for the seller, and no price reduction could compensate the buyer without imposing a net cost on the seller for the transaction. This net cost could discourage efficient transactions and redevelopment of contaminated property.

Second, James Boyd, Winston Harrington, and Molly Macauley (1996) note that if the seller is better informed than the buyer about the environmental condition of the property, then this information asymmetry can create an adverse selection problem that drives high-quality property from the market. ${ }^{22}$ Third, they also note that even if the buyer and seller are equally well informed, the government's ability to detect contaminated sites is imperfect, and current owners may keep property off the market to avoid attracting the

${ }^{21}$ See Kathleen Segerson, Liability Transfers: An Economic Assessment of Buyer and Lender Liability, 25 J. Envtl. Econ. \& Mgmt. S-46 (1993).

22 See James Boyd, Winston Harrington \& Molly K. Macauley, The Effects of Environmental Liability on Industrial Real Estate Development, 12 J. Real Est. Fin. \& Econ. 37, 46-47 (1996). Buyers can mitigate this problem by inspecting the site thoroughly before purchasing the property. See Percival et al., supra note 9, at 237 (noting that "in the great majority of cases, site assessments generally have little difficulty determining that properties are contaminated"). 
attention of regulators to contamination at the site. ${ }^{23}$ If transactions increase the probability of detection by regulators, then they increase the expected liability costs associated with the property. Once again, no price reduction could compensate the buyer for the liability imposed without also imposing a net cost on the seller for the transaction, which in turn could discourage efficient redevelopment of contaminated property.

This paper identifies four additional reasons that Superfund liability could discourage efficient transactions. Superfund liability may have these effects even if the buyer and seller are equally likely to be judgment-proof and have the same information regarding contamination at the site and even if the transaction has no effect on the probability of detection by regulators. Each effect implies a tendency for the expected costs imposed on the buyer to exceed the reduction in the expected costs enjoyed by the seller. That is, the sale of the property would increase the expected costs for the buyer and the seller taken together. This increase in their collective costs, unlike a mere transfer of liability from the seller to the buyer, could not be offset by an adjustment in the sale price and therefore would inhibit sales of contaminated properties.

All of the barriers to efficient transactions that we identify flow from the following feature of Superfund liability: If a PRP that owned the site "at the time of disposal of any hazardous substance" sells the property, then under CERCLA, after such a sale, both the buyer and the seller are PRPs. ${ }^{24}$ That is, the number of PRPs that the government can hold jointly and severally liable increases upon such a sale of the property if the buyer was not already a PRP. Furthermore, the law defines "disposal" broadly to include "the discharge, deposit, injection, dumping, spilling, leaking, or placing of any solid waste or hazardous waste into or on any land or water." 25 Given this broad definition of "disposal," some courts have held prior owners liable even if they engaged in no active disposal themselves if they owned the land while wastes previously

\footnotetext{
${ }^{23}$ See Boyd, Harrington \& Macauley, supra note 22, at 49-52.

${ }^{24} 42$ U.S.C. $\S 9607(a)(2)(2000)$.

${ }^{25}$ Solid Waste Disposal Act $\S 1004,42$ U.S.C. $\$$ 6903(3) (2000); see CERCLA, 42 U.S.C. $\S 9601(29)$ (2000) (incorporating the definition from the Solid Waste Disposal Act $\S 1004$ into CERCLA).
} 
deposited on the land continued to leak or spill during their ownership. ${ }^{26}$ The broader the definition of "disposal," the more likely courts are to hold prior owners liable as PRPs, and the more likely each sale of the property is to increase the number of PRPs.

Unlike the effects that we identify, the effects identified in the previous literature would occur even if the seller could protect itself from all liability through a sale of the property and transferred all liability to the buyer. Furthermore, most of the effects that we identify are associated with the joint and several liability imposed by Superfund, whereas the qualitative effects identified in the previous literature flow more generally from the transfer of liability to new owners, whether or not this liability is joint. Thus, the effects that we identify have different implications for law and public policy than those identified in the previous literature.

Furthermore, Sigman (2006) presents empirical evidence that joint and several liability in particular inhibits the development of contaminated sites. ${ }^{27}$ Those results suggest that joint and several liability reduces land prices and increases vacancy rates in central cities. This evidence is consistent with the theory presented in this paper.

We will present our theory using a formal model of joint and several liability based on the model we developed in Chang and Sigman (2000). ${ }^{28}$ Our model allows us to study the effects of sales of contaminated property because it allows us to vary the number of PRPs at a contaminated site. This model

\footnotetext{
${ }^{26}$ See, e.g., Nurad, Inc. v. William E. Hooper \& Sons, 966 F.2d 837, 844-46 (4 $4^{\text {th }}$ Cir. 1992) (upholding CERCLA liability for a passive prior owner), cert. denied, 506 U.S. 940 (1992); Carson Harbor Village, Ltd. v. Unocal Corp., 270 F.3d 863, 879-81 ( $9^{\text {th }}$ Cir. 2001) (holding that "disposal" under CERCLA does not include passive soil migration, but may include other passive migration, such as from leaking barrels or tanks), cert. denied, 535 U.S. 971 (2002). But see United States v. 150 Acres of Land, 204 F.3d 698, 705-06 (6 ${ }^{\text {th }}$ Cir. 2000) (limiting "disposal" under CERCLA to spills occurring by human intervention); ABB Industrial Sys. v. Prime Tech., Inc., 120 F.3d 351, 357-59 (2d Cir. 1997) (rejecting CERCLA liability for a passive prior owner); United States v. CDMG Realty Co., 96 F.3d 706, 713-18 (3d Cir. 1996) (same); United States v. Petersen Sand \& Gravel, Inc., 806 F. Supp. 1346, 1350-53 (N.D. Ill. 1992) (same).

${ }^{27}$ See Hilary Sigman, Environmental Liability and Redevelopment of Old Industrial Land (Rutgers University Department of Economics Working Paper No. 2006-09, 2006).

${ }^{28}$ See Howard F. Chang \& Hilary Sigman, Incentives to Settle under Joint and Several Liability: An Empirical Analysis of Superfund Litigation, 29 J. Leg. Stud. 205 (2000).
} 
extended the models of joint and several liability developed earlier by Lewis Kornhauser and Richard Revesz (1994), which assumed only two defendants ${ }^{29}$ and by Frank Easterbrook, William Landes, and Richard Posner (1980), which assumed perfect correlation in outcomes at trial among all defendants and costless litigation. ${ }^{30}$

\section{THEORY}

Suppose that the government brings suit under CERCLA against all available PRPs for cleanup costs at a contaminated site. The government litigates against $N$ defendants, where $N$ is an integer and $N \$ 1$. Suppose that all defendants would share liability equally if they litigate and lose at trial. Normalize the amount of damages at stake to equal one, so that if the government were to prevail at trial against all $N$ defendants, for example, each would pay $1 / N$. Let $p$ represent the probability that the government prevails against any given defendant, where $0<p<1$.

Suppose the $N$ defendants are divided into $m$ groups of different types of defendants, where $m$ is an integer and $1 \# n \# N$. The $m$ groups may be of unequal size. Within each group, the outcomes at trial are perfectly correlated across defendants. Among the $m$ groups, however, the outcomes at trial are independent. Thus, $m$ is a variable that indicates the degree to which the outcomes at trial are independent among the defendants: if $m=1$, then the outcomes are perfectly correlated among all defendants, but if $m=N$, then the outcomes are independent among all defendants. In between these polar cases is a range of cases with some mix of correlation and independence.

All parameters are common knowledge, so there is no asymmetric information in this model. We also assume that all $N$ defendants can pay the full amount of damages at stake, so none of these defendants is judgmentproof. Finally, we assume that a sale has no effect on the probability that the government detects contamination at the site. Under these assumptions, according to models in the previous literature, the threat of liability imposed

\footnotetext{
${ }^{29}$ See Lewis A. Kornhauser \& Richard L. Revesz, Multidefendant Settlements: The Impact of Joint and Several Liability, 23 J. Leg. Stud. 41 (1994).

${ }^{30}$ See Frank H. Easterbrook, William M. Landes \& Richard A. Posner, Contribution among Antitrust Defendants: A Legal and Economic Analysis, 23 J.L. \&. Econ. 331, 356-60 (1980).
} 
on buyers should not discourage the efficient transfer of contaminated property to new owners.

Nevertheless, in our model, we can distinguish four different reasons that the threat of Superfund liability would discourage sales of contaminated property. Each effect arises when a sale would increase the number of PRPs from which the government can recover cleanup costs. To illustrate the separate contributions of each of these effects of Superfund liability, we will begin with a simple version of the model, then introduce additional complexity one step at a time.

\section{A. Other Liable Defendants}

Suppose that $N>1$, so that the current owner is not the only defendant associated with the site. For simplicity, suppose also that $m=1$, so that the outcomes at trial are perfectly correlated across all defendants. In this case, the expected liability for each defendant is $p / N$.

If a sale of the property increases the number of available defendants from $N=n$ to $N=n+1$ by adding the buyer as a new PRP, then the expected liability of the buyer and the seller taken together increases from $p / n$ to $2 p /(n+1)$. Let $\Delta$ represent the magnitude of this increase:

$$
\Delta=\frac{2 p}{n+1}-\frac{p}{n},
$$

which we can express as

$$
\Delta=\frac{p(n-1)}{n(n+1)} .
$$

An inspection of equation (2) confirms that if $n>1$, then this increase is positive.

This increase in expected liability costs for the buyer and the seller as a group will discourage even efficient transactions. This effect arises because the transaction reduces the collective expected liability of PRPs other than the buyer and the seller. Although the collective expected liability of all defendants remains fixed and equal to $p$, that expected joint liability is now divided among $n+1$ defendants rather than only $n$. 
Given equation (2), we can show that the magnitude of this effect equals zero at $n=1$, is at its greatest at $n=2$ or $n=3$, when $\Delta=p / 6$, then declines as $n$ grows larger, approaching zero as $n$ goes to infinity. ${ }^{31}$ Thus, this effect is especially important if $N$ is small (but greater than one) before the sale. Given the small size of most brownfields, it is plausible that an owner contemplating a sale would anticipate that there would be very few other PRPs available as defendants in a potential lawsuit to recover cleanup costs. A recent study notes that these sites include a "large number of abandoned gas stations and garages, former dry cleaning establishments, small fabrication facilities, leaking underground storage tanks, and other facilities," and estimates that the size of the median brownfield site is probably one acre or less. ${ }^{32}$

The effect of a sale is also large if $p$ is large, that is, if liability is likely. For example, if $n=3$, the expected liability of the buyer and seller together rises from $p / 3$ to $p / 2$, which amounts to a 50 percent increase in their collective expected liability, and if $p$ is close to one, this increase approaches one-sixth of the cost of cleanup at the site. Because we have normalized the amount of damages at stake to equal one, the absolute value of this effect will also be large insofar as the amount of damages at stake is large.

We can relax the assumption that each losing defendant pays its pro rata share of the liability. ${ }^{33}$ Insofar as a sale of the property would add another PRP to the site, and as long as this increase in the number of defendants tends to reduce the share of liability paid by the defendants at trial other than the buyer and the seller of the property, the sale would confer an expected benefit external to the two parties to the sale transaction. Because the allocation of

\footnotetext{
${ }^{31}$ If we take the derivative of $\Delta$ with respect to $n$, then we can confirm that the continuous function $\Delta(n)$ expressed in equation (2) reaches a unique maximum somewhere between $n=2$ and $n=3$.

${ }^{32}$ Wernstedt, et al., supra note 7 , at 8.

${ }^{33}$ By bringing contribution actions against other PRPs, a defendant can ensure that they bear an equitable share of response costs even if the government has not filed suit against those other PRPs. Under the Uniform Contribution Among Tortfeasors Act, a defendant that has paid more than a pro rata share of a joint and several liability has a right to contribution from another defendant that has paid less. Unif. Contribution Among Tortfeasors Act $\S 1$ (b) (amended 1955), 12 U.L.A. 185, 194 (1996). Under CERCLA, however, courts "may allocate response costs among liable parties" when a private party seeks contribution from other PRPs "using such equitable factors as the court determines are appropriate." 42 U.S.C. § 9613(f)(1) (2000).
} 
this liability among the defendants is a zero-sum game, this external benefit implies a transfer from the seller and buyer taken together. The seller and buyer can adjust the sales price to shift the expected burden of CERCLA liability between themselves, but no price adjustment can capture the positive externality that the sale produces for third parties that are already PRPs at the site. Because the loss for the seller and buyer is a pure transfer, this private cost is not a social cost, and this positive externality implies that the level of sales will be inefficiently low from a social perspective. As long as $n>1$, there will be such third-party beneficiaries, and this transfer of expected value to third parties would tend to inhibit efficient transactions.

\section{B. Independent Outcomes at Trial}

If we relax the assumption that outcomes at trial are perfectly correlated across defendants, then we uncover a second reason that joint and several liability under CERCLA can inhibit development of contaminated property. This second effect arises even if the current owner is the only available defendant before any sale of the contaminated site, so that $n=1$. To see this effect, suppose that $n=1$ so that there are only two defendants after a sale. We also assume that $m=N$, that is, the outcomes at trial for the defendants are independent.

Under joint and several liability, the government need only prevail against one defendant to recover in full. The government will receive an amount equal to one at trial unless it fails against each defendant. Against each defendant, the probability of failure is 1-p. Therefore, the expected value of the damages paid by the defendants as a group and awarded to the government as a judgment at trial, which we denote $D$, is

$$
D=1-(1-p)^{m},
$$

which increases in $m$. Thus, if a sale of a contaminated site increases $m$, then the expected joint liability of the PRPs as a group will also increase as the PRPs become a more diverse set of defendants.

For example, if the sale of a site adds a second defendant so that $m=2$, then (3) implies that

$$
D=2 p-p^{2},
$$


which is greater than the $D=p$ that the government could recover when $m=1$. The increase in the expected liability of the buyer and seller taken together is the difference:

$$
\Delta=p-p^{2}
$$

which is positive, because $(1-p) p>0$ as long as $0<p<1$, that is, as long as there is some uncertainty about the outcomes at trial. ${ }^{34}$ If we take the derivative of $\Delta(p)$ in equation (5) with respect to $p$, we can show that the absolute value of this increase reaches a maximum at $p=1 / 2$, where $\Delta=1 / 4$. In this case, a sale would increase the collective expected liability of the buyer and seller by 50 percent, raising this expected liability by an amount equal to 25 percent of the cost of cleanup at the site. Thus, the absolute value of this effect will also be large when the amount of damages at stake is large.

As long as the outcome at trial for the buyer is not perfectly correlated with the outcome at trial for the seller, then the expected joint liability of the buyer and the seller as a group will increase upon sale of the property to a new owner. Given this weak assumption, the government would benefit from an increase in the number of PRPs. That is, joint and several liability would create this effect even if we relax the assumption of independent outcomes at trial and assumed some correlation instead, as long as the outcome at trial for the new owner is not perfectly correlated with the outcome at trial for the prior owner.

The magnitude of this effect, however, would depend upon the correlation in trial outcomes. If this correlation is positive, then the effect is smaller than it would be if the outcomes were independent; if this correlation is negative instead, then the effect is even greater than it would be if the outcomes were independent. The degree of correlation will also matter. For example, suppose the correlation is positive. The weaker the correlation between the outcome at trial for the buyer and the outcome at trial for the seller, the more powerful will be the effect of the addition of the new owner as a PRP.

This effect would inhibit sale of the property even if the prospective seller is the only available PRP associated with the site before any sale. Given the

\footnotetext{
34 The value of $m$ would have no effect on $D$, however, if $p=0$ or if $p=1$, that is, if the outcomes are known in advance with certainty. We can see from equation (3) that if $p=0$, then the government would receive no award at trial, regardless of the value of $m$. Similarly, we can also see from equation (3) that if $p=1$, then the government would recover all of its damages at trial, regardless of the value of $m$.
} 
small size of most brownfield sites, there may well be many cases in which an owner would consider itself likely to be the only PRP available as a defendant in a suit by the government to recover cleanup costs. The effect that we identify here could well deter many efficient transactions for such owners contemplating sale of their properties. In such cases, the government would enjoy a positive externality as a result of a sale, and this external benefit functions as a tax on the transaction. The parties to the transaction may adjust the sale price to shift the burden of their joint liability between the buyer and seller, but this price adjustment cannot capture the external benefit conferred upon the government. Because this positive externality from the transaction is a pure transfer to the government, this private cost for the defendants is not a social cost, and there will be too few transactions from a social perspective.

Suppose we now relax the assumption that $n=1$ and turn to the general case in which $n \$ 1$, but we assume that the outcome at trial for the seller is independent of the outcome at trial for the buyer. With independent outcomes at trial, we can obtain some combination of the first and second effects that we have identified from an increase in $N$. If these outcomes are perfectly correlated instead, then only the first effect that we identified would be possible. ${ }^{35}$ In cases where the new PRP would be found liable at trial along with some other defendants, the government would not benefit, but the other defendants would gain from having another defendant with which to share liability. As long as these beneficiaries include defendants other than the prior owner that sold the property to the new PRP, the buyer and the seller as a group would be worse off at trial as a result of the sale.

If the outcomes for the seller and buyer are independent, then the effect of adding the buyer as a defendant depends on three states of the world at trial. First, states in which the buyer would not be found liable, which occur with probability 1-p, would not increase the expected liability for the buyer and the seller as a group. Second, states in which the seller and buyer would both be found liable, which occur with probability $p^{2}$, would deter transactions insofar

\footnotetext{
${ }^{35}$ As long as there is at least one other defendant, this effect would be present. As we have seen, the larger the number of other defendants, the smaller the magnitude of the effect would be. The effect is at its maximum if there is one other defendant and the outcome for that defendant is perfectly correlated with the outcome for the buyer and seller. Once we relax the assumption of perfect correlation in trial outcomes, however, the magnitude would also depend on the degree of correlation among trial outcomes. To the extent that outcomes for the other defendants are independent of the outcome for the seller and buyer, so that $m>1$, those other defendants are less likely to benefit from the addition of the buyer as a PRP.
} 
as the presence of other liable defendants creates the first effect we have identified. The magnitude of this effect would depend on the probability that there will be such other defendants and their number. ${ }^{36}$ Third, states in which the buyer would be found liable but the seller would not, which occur with probability $(1-p) p$, would also deter transactions insofar as other defendants may also be found liable at trial.

As long as the outcome at trial for the buyer is not perfectly correlated with the outcome at trial for any other defendant, however, this third state of the world would also include a state in which the buyer alone would be found liable. This state would generate the second effect we have identified, which produces an external benefit for the government instead of an external benefit for other defendants. In cases where the new PRP would be found liable at trial while no other defendants are found liable, the government would benefit from having another PRP to sue.

The benefit conferred upon the government by an increase in $m$ would represent an additional effect of Superfund liability discouraging efficient sales. Given equation (3), we can take the derivative of $D$ with respect to $m$ and obtain the following equation:

$$
\frac{\partial D}{\partial m}=-\ln (1-p)(1-p)^{m} .
$$

Given equation (6), we can confirm that this derivative is positive for $0<p<1$. We can also see that the magnitude of this effect falls as $m$ grows larger and the set of defendants becomes more diverse. Therefore, this effect would be most important when $m$ is small. Given the small size of most brownfield sites, the number of PRPs and thus $m$ will often be small, which implies a significant effect from an increase in $m$.

If $n>1$ and $m$ increases, then a sale not only increases the expected joint liability to be paid by the PRPs as a group to the government but also increases the share of that expected joint cost that the buyer and the seller as a group may expect to bear. That is, even when we allow $m>1$, the first effect that we identified persists. As a result of both effects, the sale would increase the liability costs that the parties to the sale would expect to pay in subsequent litigation.

\footnotetext{
${ }^{36}$ See supra note 35.
} 


\section{Litigation Costs}

The foregoing analysis did not include litigation costs in the costs that the prospective buyer and seller would anticipate while contemplating a sale of the property. Suppose, for example, that a trial would impose $c_{d}$ in litigation costs on each defendant, where $c_{d}>0$. If a sale adds the buyer to the set of defendants without removing the seller from that set, then the litigation costs imposed on the buyer and seller as a group would double, rising from $c_{d}$ to $2 c_{d}$ as a result of the sale. The magnitude of this increase equals $c_{d}$, so that this effect will be more important when $c_{d}$ is large, that is, when litigation costs per defendant are large. Like the increase in the expected liability for cleanup costs, this increase in litigation costs for the buyer and the seller as a group would discourage the sale of the property, whether $N=1$ or $N>1$ prior to any sale.

The empirical evidence indicates that the transaction costs flowing from Superfund liability are large. These costs include not only legal fees but also other costs, including engineering studies to contest a remedy proposed by the government or to build a case against another PRP. A 1994 RAND study of Superfund sites estimated that transaction costs accounted for 32 percent of private-sector PRP expenditures through 1991, with cleanup costs accounting for the other 68 percent. ${ }^{37}$ That is, these transaction costs were equal to nearly half of the cost of cleanup itself. Furthermore, the data collected by RAND also show that at sites with relatively low cleanup costs, transaction costs accounted for a larger share of expenditures than at those with higher cleanup costs, other factors held constant. ${ }^{38}$ The median brownfield site is small and likely to have cleanup costs that are low compared to the sites studied by RAND, even if these costs are large compared to the value of the property. These facts suggest that the share of expenditures that owners expect to devote to transaction costs at most brownfields are even higher than suggested by the RAND estimates, which were based on sites on the National Priorities List.

\footnotetext{
${ }^{37}$ See Lloyd S. Dixon, The Transaction Costs Generated by Superfund's Liability Approach, in Analyzing Superfund: Economics, Science, and Law 171, 179, 183 (Richard L. Revesz \& Richard B. Stewart eds. 1995) [hereinafter Analyzing Superfund].

${ }^{38}$ See $i d$. at 177 . For example, a 1993 RAND study found that this share rises by 25 percent when we move from sites with cleanup costs greater than $\$ 75$ million to sites with cleanup costs less than \$3 million. See Lloyd S. Dixon, Deborah S. Drezner \& James K. Hammitt, Superfund: Private Sector Expenditures and Transaction Costs 37 (1993).
} 
The prospect of litigation would inhibit property sales even if we relax the assumption that the defendants' total litigation costs are proportional to the number of defendants. As long as a sale causes an increase in the collective litigation costs of the buyer and the seller through the addition of another defendant, as seems plausible, then this effect would inhibit such transactions. This increase in litigation costs seems plausible for any regime that makes both the buyer and seller liable, whether or not the liability is joint and several. This increase in litigation costs seems especially likely to be large, however, under regimes of joint and several liability like that imposed by CERCLA, where each defendant may litigate not only the issue of its own liability but also the issue of an equitable apportionment of joint liability among the defendants. The RAND data confirm that transaction costs as a share of PRP expenditures increase as the number of PRPs increases, holding other factors constant, and this increase appears to be the most dramatic for sites with relatively few PRPs. ${ }^{39}$ Given the small size of the typical brownfield site, there are likely to be few PRPs available as defendants, and the deterrent effect of an increase in litigation costs is likely to be significant.

Furthermore, the RAND data understate the litigation costs that are relevant for our model. The $c_{d}$ in our model include the costs the PRPs would bear if the government were to litigate the case and obtain a judgment in court for each defendant. Given that most cases settle out of court, the RAND data do not include all the litigation costs that can deter the sale of brownfields, because the mere threat of these litigation costs undermines the bargaining position of defendants in settlement negotiations and implies less favorable settlements for these defendants. Once we take account of settlement negotiations, as we will do next, these potential litigation costs translate into

\footnotetext{
${ }^{39}$ See Dixon, supra note 37, at 176-77. For example, a 1992 RAND study found that this share at sites with only one PRP was only 7 percent, compared to 39 percent for sites with multiple PRPs, and holding other site attributes constant, this difference came to 34 percent. See Jan Paul Acton \& Lloyd S. Dixon, Superfund and Transaction Costs: The Experience of Insurers and Very Large Industrial Firms 51, 52, 61 (1992). Similarly, a 1993 RAND study found that holding other site attributes constant, this share increased by 35 percent when we move from sites with one PRP to sites with 2 to 15 PRPs, by 29 percent when we move from sites with 15 or fewer PRPs to sites with 16 to 100 PRPs, and by 6 percent when we move from sites with 16 to 100 PRPs to sites with more than 100 PRPs. See Dixon, Drezner \& Hammitt, supra note 38, at 37. In terms of our model, an increase in this share from 7 percent for a site with one PRP to 42 percent for a site with 2 to 15 PRPs, for example, would amount to an increase in litigation costs from 8 percent of the cost of cleanup to 72 percent of the cost of cleanup.
} 
larger transfers to the government in settlements to pay for cleanup costs. Thus, the deterrent effect of litigation costs is probably much larger than suggested by the RAND data.

If sales of brownfields inevitably entail an increase in these transaction costs, then we might deem it appropriate from the standpoint of economic efficiency that owners refrain from sales to avoid these costs insofar as these costs are social costs and not merely private costs for the PRPs. To the extent that proposed reforms of the liability regime can reduce these costs, however, the tendency for these costs to deter transactions that are otherwise efficient militates in favor of those reforms. Furthermore, as we will see next, settlement negotiations tend to convert the defendant's litigation costs into transfers to the government, so that these costs operate as a tax on transactions. This tax serves to deter efficient transactions, because the private costs imposed on the buyer and seller are not social costs.

\section{Settlements}

So far we have assumed that the government would litigate against all defendants rather than settle out of court with any defendants. The three effects we have identified so far all would make such litigation more costly for the seller and buyer of a brownfield site taken together, which would tend to deter a sale. To complete the analysis, we must explore the extent to which these three deterrent effects persist once we allow for the possibility of a settlement. Unfortunately, the analysis of settlement negotiations among a plaintiff and $N$ defendants is quite complex, and the existing literature does not include a comprehensive analysis deriving the equilibrium for a bargaining game in a completely general case. Instead, this literature had identified equilibria in specific bargaining games with restrictive assumptions that render the problem tractable. While we make a modest contribution to the extension of prior results to more general models, our primary contribution here is to provide a synthesis of the solutions derived in the existing literature for special cases and to explore the general lessons that we can draw from those cases for the problem of brownfields.

Once we allow for settlement negotiations, we find that each of the three effects that we have already identified can continue to deter sales of brownfield sites. This result is not surprising, because these effects all shift the threat point in such negotiations against the buyer and seller of a brownfield site. Furthermore, we find that settlement negotiations can add yet 
another reason for the risk of Superfund liability to inhibit development of contaminated property: an increase in the number of defendants may increase the government's ability to exploit a "prisoner's dilemma" among the defendants in a race to settle with the government.

\section{Correlated Outcomes at Trial}

An increase in the number of defendants would increase the total amount that the government could extract in a settlement with the defendants as a group. This effect is not just an implication of the effects we have already discussed: this effect is present even if $N=1$ prior to a sale, even if outcomes at trial are perfectly correlated, and even if litigation is costless for the defendants. To illustrate this effect and to develop the basic intuition, we begin with a simple case. To see this effect isolated from the other effects that we have identified, we first assume that the owner is the only available PRP before a sale $(n=1)$, outcomes at trial are perfectly correlated among all defendants $(m=1)$, and litigation is costless $\left(c_{d}=0\right)$. All parties are risk neutral, and each seeks to maximize its expected payoff.

a. Two Defendants and Zero Litigation Costs. With perfectly correlated trial outcomes, the government can expect to recover $D=p$ at trial regardless of the number of defendants and could settle for that amount. If $N>1$, however, then the government can do better than that in settlement negotiations. Suppose a sale increases the number of defendants from $N=1$ to $N=2$, then consider what happens if the government settles with one defendant for an amount $s$. Under CERCLA's "pro tanto" setoff rule, if a defendant settles with the government, then the court reduces the government's claim against any nonsettling defendants by the amount paid by the settling defendant in the settlement. $^{40}$ Therefore, the government's claim against the nonsettling defendant would have an expected value of $(1-s) p$, which the government could either obtain through litigation or extract in a subsequent settlement with the second defendant. As a result of this strategy, the government would obtain $s+(1-s) p$, which equals

\footnotetext{
${ }^{40}$ See 42 U.S.C. § 9613(f)(2) (2000). Daniel Klerman, Settling Multidefendant Lawsuits: The Advantage of Conditional Setoff Rules, 25 J. Legal Stud. 445 (1996), refers to such a setoff rule as an "unconditional" pro tanto setoff rule, because the court applies this setoff without inquiring into whether the settling defendants were actually liable.
} 


$$
p+(1-p) s
$$

As long as $s>0$ and $p<1$, this payoff is greater than the $p$ that the government could have obtained by litigating against both PRPs or by litigating against a single PRP in the absence of a second PRP. The government gains because it gets $s$ for certain in a settlement and loses $s$ through the setoff only in the state of the world in which it prevails at trial. Therefore, the government would rather settle with at least one defendant for any positive amount than litigate with both.

The government could, for example, settle with one defendant for an amount equal to that defendant's expected liability if the government were to litigate against both defendants, so that $s=p / 2$. The government would then expect to get $(1-s) p=p-p^{2} / 2$ from the second defendant, either through litigation or a subsequent settlement, which is greater than the $p / 2$ that it could have expected from the second defendant if the government had litigated against both. Thus, this settlement makes the government better off at the expense of the nonsettling defendant. With this settlement, the nonsettling defendant suffers because its gain from the setoff is too small to compensate for the loss flowing from the absence of another defendant with which to share liability for any award at trial. ${ }^{41}$

The government can do still better, however, if it can settle for a larger amount with the first defendant. We can see from the expression in (7) that the government would prefer a larger settlement amount, because the government's payoff is increasing in the settlement amount $s$. The government can extract a better settlement with the first defendant by exploiting the negative externality that a settlement would generate for the nonsettling defendant.

In particular, suppose that the government announces that it will settle with one defendant before negotiating with the other defendant over a second settlement, and then holds an auction to determine which defendant will settle with the government first. ${ }^{42}$ The government invites the defendants to submit

\footnotetext{
${ }^{41}$ CERCLA protects a settling PRP from contribution actions brought by other PRPs. See 42 U.S.C. $\S 9613(f)(2)(2000)$.

42 This strategy is based on the bargaining process described by Easterbrook, Landes \& Posner, supra note 30, at 356-60. As noted by Kornhauser and Revesz, supra note 29, at 70 n.63, the "bargaining model is not fully specified" in the description by Easterbrook, Landes, and Posner. We provide a more complete specification, making explicit the features implicit
} 
bids simultaneously and announces that it will settle with the highest bidder for the amount offered by that bidder. ${ }^{43}$ The government also announces that if the defendants submit the same bid, the government would settle with one defendant chosen at random before negotiating with the other defendant regarding a second settlement. If the defendants compete to settle first, each defendant increases its bid along a continuous action space until the proposed settlement amount is large enough to make it indifferent between settling first and settling second. Each will stop at that point, because bidding any higher would lead each to strictly prefer not to settle first, and both submit the same bid. Only this pair of identical bids is a Nash equilibrium of this bargaining game. This equilibrium occurs when the setoff is large enough to compensate the nonsettling defendant for the loss of another defendant with which to share liability, thereby eliminating the negative externality from the first settlement. At the equilibrium settlement amount,

$$
s=(1-s) p
$$

Solving equation (8) for $s$, we obtain:

$$
s=\frac{p}{p+1}
$$

which is also the expected liability of the nonsettling defendant if the government were to litigate after settling with the first defendant for this amount. Therefore, in equilibrium, the government can settle with each defendant in sequence for the same amount $s$.

This equilibrium maximizes the government's payoff. The government can do no better by settling with both defendants simultaneously. Suppose settlement negotiations take the form of the following bargaining game.

in that model.

${ }^{43}$ We assume that the government can commit itself to its bargaining strategy. Similarly, Kornhauser and Revesz, supra note 29, at 58 n.45, assume that the plaintiff can commit itself to litigate against any defendant that rejects a settlement offer. These assumptions seem especially reasonable in the Superfund context, in which the plaintiff (the government) is an extreme example of a repeat player that has much to gain by building a reputation for carrying out the threats that it makes in the course of settlement negotiations. 
Suppose that the government makes "take it or leave it" offers to settle with the defendants for the amounts $s_{1}$ and $s_{2}$, with defendant $i$ paying $s_{i}$, where $0 \# \#_{i} \# 1$ and $i=1,2$. The defendants receive their offers simultaneously, and each must either accept the offer and pay $s_{i}$ in a settlement or reject the offer. The defendants respond simultaneously, independently, and non-cooperatively to the plaintiff's settlement offer. Each party seeks to maximize its expected payoff within the constraints of this framework.

Consider a defendant's decision whether to accept such a settlement offer or to litigate instead. It would be a Nash equilibrium for each defendant to accept the offer if each defendant expects litigating against the government alone (after the other defendant has accepted its offer) to yield an expected liability at least equal to $s_{i}$. For example, defendant 1 would calculate the expected payoff from rejecting an offer to settle for $s_{1}$ when defendant 2 has accepted its offer, taking into account the setoff that a court would apply as a result of defendant 2 settling for $s_{2}$. If defendant 1 rejects the settlement offer and chooses instead to litigate alone, then it would face a probability of $p$ of being held liable for $1-s_{2}$ in damages. Therefore, for defendant 1 to accept the offer to settle, $s_{1} \#\left(1-s_{2}\right) p$ is a necessary condition. To maximize its payoff, the government would choose the largest amount $s_{1}$ that satisfies this condition, which yields:

$$
S_{1}=\left(1-S_{2}\right) p
$$

as the optimal offer for the government. By similar reasoning,

$$
s_{2}=\left(1-s_{1}\right) p \text {. }
$$

Solving equations (10) and (11) simultaneously for $s_{1}$ and $s_{2}$, we obtain:

$$
s_{1}=s_{2}=\frac{p}{p+1}
$$

as the largest amount that the government could obtain from each defendant in a settlement with both. That is, for each defendant, the government would propose the same settlement amount $s$ that appears in equation (9), which the government could have obtained through the auction described earlier.

It would be a Nash equilibrium for both defendants to accept this offer. Kornhauser and Revesz note that it is also a Nash equilibrium for both 
defendants to reject this offer and litigate instead, and that the litigation equilibrium is Pareto superior to the settlement equilibrium for the defendants. ${ }^{44}$ Rejecting the offer yields a better outcome for the defendants, however, only because Kornhauser and Revesz assume that litigation against both defendants is the government's only threat in the event that both defendants reject the offer. ${ }^{45}$ In a more general model, the government could threaten to hold the auction described earlier, which would yield the same settlement amounts, $s=p /(p+1)$ for each defendant, as the amounts proposed by the government in its offer. With this auction as the threat in the event both reject the offer, the government can obtain the maximum possible settlement, $s=p /(p+1)$, from each defendant. If at least one defendant accepts the government's offer, then the government can obtain this amount without actually holding the auction.

The buyer and seller as a group are worse off after a sale because the increase in the number of defendants creates a prisoner's dilemma in settlement negotiations, which effects a transfer to the government. The amount that the government can extract from them increases from $p$ to $2 p /(p+1)$ with a sale, and we can express the increase as follows:

$$
\Delta=\frac{p(1-p)}{p+1}
$$

which is positive as long as $0<p<1 .{ }^{46}$ By taking the derivative of $\Delta(p)$ in equation (13) with respect to $p$, we can show that this increase reaches a

${ }^{44}$ See Kornhauser \& Revesz, supra note 29, at 64.

${ }^{45}$ Others have observed the same two Nash equilibria in models similar to the model used by Kornhauser and Revesz. See Marcel Kahan, The Incentive Effects of Settlements under Joint and Several Liability, 16 Int'1 Rev. L. \& Econ. 389, 391 n.7 (1996); A. Mitchell Polinsky \& Steven Shavell, Contribution and Claim Reduction among Antitrust Defendants: An Economic Analysis, 33 Stan. L. Rev. 447, 470-71 (1981).

${ }^{46}$ If $p=0$, then the government would be certain to lose at trial and would be unable to recover any of its cleanup costs in a settlement, regardless of the number of defendants, so that an increase in $N$ would have no effect. If $p=1$ instead, then the defendants would be certain to lose at trial, and the government would be able to recover all of its cleanup costs in a settlement, regardless of the number of defendants, so that an increase in $N$ would have no effect. 
maximum at $p=0.4142$, when the amount paid to the government increases from 0.4142 to 0.5858 . In this case, a sale causes a 41 percent increase in the value of the transfer to the government, an increase equal to 17 percent of the cost of cleanup.

b. Other Defendants and Litigation Costs. Now we allow the number of PRPs prior to a sale, $n$, to be greater than one. As shown by Easterbrook, Landes, and Posner of the University of Chicago, the same reasoning we used in the case of two defendants also applies to the more general case of settlement negotiations with $N$ defendants. ${ }^{47}$ Each defendant settles for the same amount $s$, which equals the expected liability of a nonsettling defendant litigating alone against the government after all the other $N-1$ defendants have settled for the same amount $s .{ }^{48}$ We can extend their result further by introducing positive litigation costs equal to $c_{d}>0$ for each defendant. Note that a court would hold a lone nonsettling defendant liable for 1-(N-1)s with probability $p$, and the defendant would also bear $c_{d}$ in litigation costs. Therefore, each defendant would settle for the amount $s$ that solves the following equation:

$$
s=[1-(N-1) s] p+c_{d}
$$

Solving equation (14) for $s$, we derive

$$
s=\frac{p+c_{d}}{N p+1-p}
$$

${ }^{47}$ See Easterbrook, Landes \& Posner, supra note 30, at 356-60. We can, for example, consider a sequence of $N$ settlements with one defendant at a time, after $N-1$ auctions to see which defendant will settle next. By using backward induction, we can show that each defendant will submit the same bid in each auction, and the settlement amount proposed in each bid equals the expected liability of the last nonsettling defendant if it litigates alone against the government. This equilibrium yields the maximum payoff for the government.

\footnotetext{
${ }^{48}$ Note that this result does not depend on an assumption that each defendant would pay a pro rata share of damages awarded at trial: because each defendant faces the threat of litigating alone, each would pay the same amount in a settlement even if defendants would pay unequal amounts at a trial in which multiple defendants were to lose.
} 
as the equilibrium settlement. We will refer to this outcome as the Chicago settlement.

Although this settlement amount is decreasing in $N$, the total amount received by the government, $S=s N$, increases in $N$. To see this result, take the derivative of

$$
S=\frac{\left(p+c_{d}\right) N}{N p+1-p}
$$

with respect to $N$. This partial derivative

$$
\frac{\partial S}{\partial N}=\frac{\left(p+c_{d}\right)(1-p)}{(N p+1-p)^{2}}
$$

is positive as long as $p<1$, that is, as long as the defendants are not certain to lose at trial.

Note that both $s$ and $S$ increase in $c_{d}$, because the government can extract more from each defendant in a settlement if each faces the prospect of large litigation costs if it goes to trial alone. As long as we assume that litigation costs and $N$ are not too large, specifically, that

$$
c_{d} N<(1-p),
$$

then $S<1$. That is, under these conditions, the defendants will be willing to pay less than the full amount at stake in a settlement, and the government could recover more of its cleanup costs through settlements if either $N$ or $c_{d}$ increases.

Thus, we see that if a sale of a contaminated site increases the number of PRPs available for the government to sue, then it will increase the maximum amount that the government can extract in a settlement with the defendants. We also see that if there are other defendants with which the buyer and seller may share liability (that is, if $n>1$ ), increases in $N$ also generate a benefit for each of these other defendants, because each one pays a smaller amount in a settlement as $N$ increases. In such a case, the fourth effect that we have identified accompanies a modified version of the first effect we identified, insofar as a sale of the site generates a positive externality for defendants other than the seller and buyer. Given that the allocation of cleanup costs among the 
parties is a zero-sum game, these positive externalities for these other defendants and for the government imply transfers from the seller and buyer as a group. Like the second effect we identified, the benefit for the government from increases in $N$ would function as a tax on sales of contaminated property, which would tend to discourage the efficient development of these sites.

We can confirm an adverse effect of a sale for the buyer and the seller as a group in this more general $N$-defendant case if we consider an increase from $N=n$ to $N=n+1$. Substituting $n+1$ and $n$ for $N$ in our expression for the settlement amount $s$, we can express the increase in the amount that the seller and buyer together pay to the government as the following difference:

$$
\Delta=\frac{2\left(p+c_{d}\right)}{n p+1}-\frac{p+c_{d}}{n p+1-p},
$$

which simplifies to the following equation:

$$
\Delta=\frac{\left(p+c_{d}\right)[1+(n-2) p]}{[(n-1) p+1](n p+1)},
$$

which is positive. We can see from equation (20), however, that the magnitude of this effect approaches zero as $n$ goes to infinity, so that the deterrent effect of an increase in $N$ is most important when there are relatively few PRPs from which the government may recover cleanup costs.

Finally, we can also see from equation (20) that the magnitude of this effect increases in the defendants' litigation costs $c_{d}$. Thus, our earlier calculation of the maximum possible magnitude of this effect in the $n=1$ case, based on our assumption that $c_{d}=0$, would be an underestimate of that maximum possible effect. One should not confuse this effect of litigation costs with the third effect of an increase in $N$ that we have identified. Here litigation costs instead magnify the fourth effect that we have identified. This magnifying effect depends only on the cost of litigating against the government alone, not on the magnitude of the increase in the defendants' collective litigation costs when $N$ increases. The effect of an increase in $N$ is large here if $c_{d}$ is large, simply because the government can extract more from the buyer in a settlement if each defendant faces the prospect of large litigation costs if it goes to trial alone. Thus, if those litigation costs are large, then the deterrent effect of an increase in $N$ on sales is magnified, regardless of the 
effect of an increase in $N$ on the total litigation costs of the defendants as a group.

\section{Independent Outcomes at Trial}

Next we turn to the case of independent trial outcomes. To develop the basic intuition for the results here, we will assume independent trial outcomes among all $N$ defendants $(m=N)$ and begin with the simple case of only one PRP prior to a sale $(n=1)$ and zero litigation costs $\left(c_{d}=0\right)$. In this case, as we can see from equation (4), the government expects to recover $D=(2-p) p$ if it litigates against both defendants. This expected payoff is greater than the $p$ the government could expect from litigating against both defendants in the case of perfectly correlated outcomes, because $2-p>1$. That is, litigation against both defendants becomes more attractive for the government as the correlation in trial outcomes falls.

In this case, the government can still settle using the bargaining strategies discussed earlier and obtain $p /(1+p)$ from each defendant. That equilibrium settlement amount does not depend on the value of $m$ at all, as each defendant considers the prospect of litigating against the government by itself after the other defendant settles, when there would be no other defendant that might also lose at trial and share liability. With independent outcomes at trial, however, the government's maximum payoff from settlement is no longer greater than its payoff from litigating against both defendants. Instead, the government would receive less by settling than it could expect to recover by litigating against both defendants:

$$
\frac{2 p}{p+1}<(2-p) p
$$

which we can show is true if and only if $0<p(1-p)$. Thus, this result holds as long as there is some uncertainty regarding the outcomes at a trial (that is, as long as $0<p<1$ ).

To see the same point another way, consider what would happen if the government were to settle with one defendant for the expected liability of that defendant if the government were to litigate against both defendants instead, that is, for $s=(2-p) p / 2$. Because this amount (unlike the $p / 2$ we considered in the case of perfect correlation among trial outcomes) is larger than the equilibrium settlement amount, $p /(p+1)$, a nonsettling defendant would enjoy 
a positive externality from such a large settlement. The setoff from such a settlement is so large, and the loss to a nonsettling defendant from being deprived of the opportunity to share liability with the settling defendant is so small (because the chance that the defendants would share liability at trial is reduced with independent outcomes), that the nonsettling defendant's prospects actually improve with such a settlement. Given this positive externality, each defendant would prefer that the other defendant settle first for such a large amount. Furthermore, given that the allocation of cleanup costs is a zero-sum game, we know that the gain from such a settlement for the nonsettling defendant is a loss for the government. Therefore, it would not be a Nash equilibrium for the defendants to accept a settlement offer from the government for any amount large enough to compensate the government for the lost opportunity to litigate against both defendants. Kornhauser and Revesz conclude that under these circumstances, the government would choose to litigate against both defendants rather than settle with either or with both. ${ }^{49}$

Now relax the assumption that $n=1$, and suppose that litigation costs are strictly positive for all parties rather than zero. Litigation would impose a cost $c_{p}$ on the plaintiff and a cost $c_{d}$ on each defendant, where $c_{p}>0$ and $c_{d}>0$. The government now has an incentive to settle, because it would like to avoid its litigation costs. Furthermore, as we have seen, litigation costs for the defendants increases the maximum amount that the government can extract from them in a settlement. Note that the government would settle for an amount $S$ from all the defendants rather than litigate against all of them only if

$$
S \$ S_{p}
$$

where $S_{p}$ represents the government's expected payoff from litigating against all $N$ defendants. That is, $S_{p}=D-c_{p}$, or:

$$
S_{p}=1-(1-p)^{m}-c_{p}
$$

\footnotetext{
${ }^{49}$ See Kornhauser \& Revesz, supra note 29, at 52-53. Assuming that defendants losing at trial would pay equal shares, we extend this result from the case of two defendants to the more general case of $N$ defendants with independent outcomes at trial. See Appendix. In this case, the government would again choose to litigate against all defendants rather than settle with any.
} 
If litigation costs are large enough, the maximum amount $S$ that the government can obtain in a settlement may exceed $S_{p}$, which would imply a settlement instead of litigation against all defendants.

Even when the payoff from a Chicago settlement is less than $S_{p}$, however, the government would avoid litigation if we relax an assumption that has been implicit in our analysis so far. Kornhauser and Revesz make this assumption explicitly, which prevents the government from making a settlement offer that binds the parties only if all defendants accept the offer. ${ }^{50}$ As John Donohue points out, if we allow the government to make settlement offers that are contingent on acceptance by all defendants, then the government can settle with all defendants, even in cases in which the amount that would result from a Chicago settlement is less than $S_{p}$ because outcomes at trial are independent. ${ }^{51}$ That is, such offers allow the government to avoid the obstacle to settlement that flows from joint and several liability and the pro tanto setoff rule because these offers eliminate the possibility that nonsettling defendants could enjoy a positive externality from the government settling with other defendants for large amounts.

Indeed, if the government can make these offers on a "take it or leave it" basis, so that the government litigates against all defendants if any defendant rejects the offer, then the government can capture the entire surplus produced for the parties by avoiding litigation costs. The government could offer to settle with each defendant for an amount equal to the defendant's litigation costs plus its expected liability if the government litigates against all defendants. The government would thereby receive

$$
S=1-(1-p)^{m}+N c_{d}
$$

from all the defendants together, yielding a total settlement greater than $S_{p}$. We will refer to this outcome as a Donohue settlement. In such a settlement, each defendant pays what it would expect to pay in the event that the government litigates against all defendants. Therefore, this settlement would

\footnotetext{
${ }^{50}$ See Kornhauser \& Revesz, supra note 29, at 48-49.

${ }^{51}$ See John J. Donohue III, The Effect of Joint and Several Liability on the Settlement Rate - Mathematical Symmetries and Metaissues about Rational Litigant Behavior: Comment on Kornhauser and Revesz, 23 J. Legal Stud. 543, 555-56 (1994).
} 
preserve all of the first three deterrent effects we described as flowing from an increase in $N$.

\section{Implications for the General Case}

What lessons can we draw from these special cases for the more general case that allows for asymmetric relationships among trial outcomes for the defendants $(1<m<N)$ ? Given the option of a Donohue settlement and the presence of positive litigation costs, settlements would always occur under our assumptions, and the government can always extract an amount equal to its expected recovery $D$ from litigation against all $N$ defendants plus the total litigation costs that the defendants would bear from going to trial. Under the Donohue settlement, a sale of a brownfield site could still trigger all of the first three deterrent effects that we have outlined by adding another PRP that the government can sue.

As we have seen, however, if outcomes among defendants are sufficiently correlated, then the government can extract even more by exploiting a race among the defendants to settle first. Thus, the government would obtain at least the Donohue settlement amount and may do even better in some cases. In a Chicago settlement, the fourth effect that we identify would replace the second and third effects that we identify, although the first effect persists in a modified form. Under the Chicago settlement, an increase in $N$ effects a transfer to the government either by creating a race to settle where none existed before or by increasing the government's yield from exploiting such a race. More generally, the optimal strategy for the government may include the use of both Chicago auctions and Donohue settlements in some combination. Let $S_{d}$ represent the total amount that the government receives using the optimal settlement strategy. Positive litigation costs and the option of a Donohue settlement together ensure that $S_{p}<S_{d}$.

In any event, we would generally expect the sale of a brownfield site to effect a transfer from the seller and buyer as a group through at least one of these various effects we have identified. Without solving for the bargaining equilibrium in the general case for all possible circumstances, however, we cannot rule out the possibility that in some perverse cases the seller and buyer as a group might instead enjoy a net gain from the increase in $N$ flowing from the sale of a brownfield site. Nevertheless, our analysis leads us to believe that such cases, if they occur, would be unusual exceptions to the general rule. 
Some general observations support our conclusion that the seller and buyer are likely to effect a transfer to other parties through a sale of a brownfield site.

First, an increase in $N$ would generally increase transfers to the government and could never decrease them. If the addition of a defendant were ever to worsen the government's prospects somehow, then the government could always settle with that defendant for a nominal amount and thereby remove that defendant from the bargaining game. Normally, we would expect an increase in $N$ to improve the government's prospects instead, through some combination of the effects that we identify. Thus, an increase in $N$ flowing from a sale would generally increase the amount extracted by the government from the defendants collectively, including the buyer that has become the new PRP.

Given this observation, it seems likely that the buyer and seller as a group would transfer wealth to other parties through the sale. We know the expected liability and potential litigation costs for the buyer has increased through the sale, as long as the buyer was not already a PRP prior to the sale. For the buyer and seller as a group to enjoy a net gain from an increase in $N$ despite the adverse effects for the buyer, the seller would have to gain enough to offset the loss for the buyer. For the seller to gain this much, it must enjoy an unusually large gain from the addition of the buyer as a PRP. The average PRP prior to a sale would certainly not gain that much from the sale, because if the government gains from the addition of the buyer as a PRP, then all $n$ of the original PRPs, including the seller, together do not gain enough to offset the loss to the buyer. Thus, it would be a rare case indeed in which the seller alone would gain enough to allow the buyer and seller to gain as a group from the addition of the buyer as a PRP.

The preceding analysis has assumed that the defendants do not cooperate in their negotiations with the government, which can therefore extract the full surplus generated by a settlement for the parties. We can instead relax the assumptions that only the government can make "take it or leave it" settlement offers and that the defendants respond independently without cooperating with one another. A more general model might allow the defendants to exercise some bargaining power in settlement negotiations, so that settlements do not necessarily allow the government to extract the maximum possible amount from the defendants. Instead, we might assume that when a settlement is possible $\left(S_{p}<S_{d}\right)$, the settlement that emerges from successful negotiations would fall somewhere in the possible settlement range, with the expected 
value of the settlement amount determined by the parties' relative bargaining power:

$$
S=\alpha S_{p}+(1-\alpha) S_{d},
$$

where $\alpha$ is a variable reflecting the defendants' relative bargaining power, and $0 \# \alpha \# 1$.

Suppose, for example, that with probability $\alpha$, the defendants make a "take it or leave it" offer to the government, and with probability $1-\alpha$, the government makes a "take it or leave it" offer to the defendants. If the defendants make the offer, we would expect $S_{p}$ as the settlement amount. If the government makes the offer, we would generally expect $S_{d}$ instead as the settlement amount.

If $\alpha$ is a fixed parameter, then we would still expect an increase in $N$ to lead to an increase in the settlement amount $S$, which is a weighted average of $S_{p}$ and $S_{d}$, because an increase in $N$ would generally increase $S_{d}$. If the defendants' litigation costs are large, then this effect would be especially significant. Moreover, if the addition of a new PRP also causes $m$ to rise, then $S_{p}$ would also increase, adding still another reason for the settlement amount $S$ to increase. For the reasons we have discussed, this increase in the settlement amount makes it likely that the seller and the buyer make themselves worse off as a group by increasing the number of PRPs.

Furthermore, if $\alpha$ is a function of $N$ rather than a fixed parameter, then we would generally expect an increase in $N$ to cause $\alpha$ to fall. That is, we would expect the derivative of $\alpha$ with respect to $N$ to be negative:

$$
\alpha \Lambda(N)<0 .
$$

A larger number of defendants seems likely to reduce the defendants' bargaining power by making cooperation among them in settlement negotiations more difficult. If the defendants' relative bargaining power falls with $N$, then the resulting settlement in equation (25) would move away from $S_{p}$ and up toward $S_{d}$, thereby reducing the defendants' payoff still more.

For all these reasons, the addition of a new PRP would usually shift settlements in favor of the government. This transfer of expected value to the government would tend to make the buyer and the seller as a group worse off after a sale in most cases. This effect would thereby discourage even efficient sales of contaminated property, because an adjustment in the sale price could 
not capture the benefits derived by the government or by PRPs other than the seller and buyer from the sale.

\section{CONCLUSION}

We distinguish four different reasons for Superfund liability to discourage the purchase of contaminated property. These four effects all arise because a sale may increase the number of defendants in a suit to recover cleanup costs. First, a sale may increase the share of liability that a seller and a buyer may expect to pay as a group. Second, a sale may increase the amount of damages that the government can expect to recover at trial. Third, a sale may increase the total litigation costs that a seller and a buyer may face as a group. Fourth, a sale may increase the amount that the government can expect to extract in a settlement with the PRPs. Each of these effects may interfere with the efficient redevelopment of contaminated sites.

Our analysis also identifies circumstances in which the four distorting effects we identify are most likely to be significant. Most of these circumstances would not seem relevant if the deterrent effects of Superfund liability derived only from the circumstances identified in the previous literature. If the defendants face large litigation costs, for example, the magnitudes of the third and fourth effects that we identify will be large. Furthermore, the magnitudes of all four effects that we describe will be large when the number of PRPs is small (although the first effect is absent entirely if the buyer and seller are the only available defendants). Finally, all these effects are largest when a sale is most likely to increase the number of liable PRPs, that is, when both the buyer and seller are likely to be liable as PRPs after the sale.

We have noted empirical evidence suggesting that at least some of these effects are likely to be important at most brownfield sites. At many such sites, owners contemplating a sale are likely to regard themselves as the only PRP available or only one of two or three available PRPs, and we have shown that the effects we identify will be especially large under those circumstances. We suspect that at least one of these four effects is an important deterrent to sales at most such sites, with the first and third effects likely to be significant at many such sites, and the second and fourth effects likely to be significant at some sites. We have also discussed how our results are likely to be robust to a wide variety of changes in the assumptions of our formal model. The 
possibility of settlements, for example, not only preserves the possibility of the first three effects that we identify but also adds the fourth effect as yet another possible deterrent to sales of brownfield sites.

The four effects that we identify suggest some disadvantages associated with joint and several liability under CERCLA. These effects provide some support for efforts to restrict the scope of this joint and several liability. These efforts include, for example, the efforts of the EPA, Congress, and the states to protect purchasers from Superfund liability. If a buyer knows for certain that it would not be liable, then the effects we identify are absent entirely. ${ }^{52}$ If the buyer is likely not to be liable, then the expected magnitude of these effects will be small. Thus, by reducing or eliminating the probability that a purchaser would be liable, these policies avoid or mitigate the deleterious effects that the threat of Superfund liability can have on the incentives to buy contaminated property. ${ }^{53}$ The less likely the seller is to be liable as a prior owner after the sale, however, the less likely a sale is to increase the number of PRPs, and the weaker the case for protecting the buyer from liability. The buyer has a better case for relief from liability when the seller is likely to be liable as a prior owner, especially if the number of PRPs at the site is small.

Courts may also take the effects that we analyze into account when they consider whether to adopt interpretations of CERCLA that protect sellers rather than buyers from Superfund liability. For example, the effects that we identify militate against a broad interpretation of the term "disposal" in CERCLA's liability provision, which makes prior owners liable as PRPs if they owned the site "at the time of disposal of any hazardous substance." Courts have divided on the appropriate interpretation of "disposal" in this provision, with courts adopting broader interpretations holding a larger class of prior owners liable. The larger the class of prior owners that are liable, the

\footnotetext{
${ }^{52}$ Efforts to provide relief to buyers may fall short of such certainty because they require the buyer to meet various conditions in order to qualify for relief. Under the Brownfields Act, for example, a "bona fide prospective purchaser" must establish that it has exercised "appropriate care with respect to hazardous substances found at the facility" in order to avoid liability. 42 U.S.C.A. § 9601(40) (West Supp. 2005).

${ }^{53}$ A more general model would allow each defendant to have its own individual probability $p_{i}$ of losing at trial, where $i=1, \ldots, N$. To the extent that a new PRP is unlikely to be held liable, so that its $p_{i}$ is small, the addition of that PRP would have little effect on the payoffs that we analyze in our model. Thus, reforms that reduce the probability of liability for a new PRP would mitigate the deterrent effects we identify. These effects would remain significant, however, insofar as the probability of liability for a new owner remains high.
} 
larger the set of owners that will be discouraged by Superfund liability from selling the property. These owners cannot avoid Superfund liability by selling the property (even at a discount) and therefore have diminished incentives to sell, even when such a sale would be efficient. The case for protecting the prior owner from liability grows weaker, however, as buyers become more likely to enjoy protection from liability.

The effects we identify, however, are only a few of the many considerations to weigh in a more comprehensive analysis of the costs and benefits of these policy alternatives. There are many other reasons militating in favor or against these policies. For example, a broader scope for joint and several liability may affect incentives for the parties to settle out of court, thereby avoiding costly litigation. ${ }^{54}$ These rules may also affect incentives for precaution against environmental contamination. ${ }^{55}$ Expanding the class of parties from which the government can recover full damages may promote the internalization of negative externalities, especially in the presence of judgment-proof PRPs, which in turn would improve the incentives to reduce contamination. ${ }^{56}$ Finally, joint and several liability under Superfund may also raise issues of fairness. ${ }^{57}$ While such a comprehensive normative analysis is beyond the scope of this paper, we hope to inform these debates by contributing to a more complete picture of the effects of Superfund liability on the incentives to develop contaminated property.

\footnotetext{
${ }^{54}$ See Chang \& Sigman, supra note 28; Kornhauser \& Revesz, supra note 29.

${ }^{55}$ See Kahan, supra note 45; Lewis A. Kornhauser \& Richard L. Revesz, Evaluating the Effects of Alternative Superfund Liability Rules, in Analyzing Superfund, supra note 37, at 115, 116-28; A. Mitchell Polinsky \& Daniel L. Rubinfeld, The Deterrent Effects of Settlements and Trials, 8 Int'1 Rev. L. \& Econ. 109 (1988); Kathryn E. Spier, A Note on Joint and Several Liability: Insolvency, Settlement, and Incentives, 23 J. Legal Stud. 559 (1994); Tom H. Tietenberg, Indivisible Toxic Torts: The Economics of Joint and Several Liability, 65 Land Econ. 305 (1989).

${ }^{56}$ See Kathleen Segerson, Property Transfers and Environmental Pollution: Incentive Effects of Alternative Policies, 70 Land Econ. 261 (1994).

${ }^{57}$ See David B. Spence, Imposing Individual Liability as a Legislative Policy Choice: Holmesian "Intuitions" and Superfund Reform, 93 Nw. U. L. Rev. 389 (1999).
} 


\begin{abstract}
APPENDIX
In this appendix, we prove the proposition that the government will not settle with any defendants if outcomes at trial are independent $(m=N)$, defendants losing at trial would pay equal shares, litigation costs are zero, and the government cannot make settlement offers that bind only if all defendants accept. This proof extends this result from the two-defendant case to the general $N$-defendant case in which $N \$ 1$. We have shown elsewhere that the government would not settle with all defendants in this case. ${ }^{58}$ Now suppose that the government decides to settle with $k$ defendants for a total amount $S$ and litigate against the other $N-k$ defendants, where $1 \# k<N$. The government would then receive the following payoff:
\end{abstract}

$$
S+(1-S)\left[1-(1-p)^{N-k}\right] \text {. }
$$

We can express this payoff as follows:

$$
1-(1-p)^{N-k}+S(1-p)^{N-k} .
$$

We can see from this expression that if the government settles with these defendants, it will prefer the largest settlement amount $S$ that it can obtain from the defendants. For the government to prefer this settlement over litigation against all $N$ defendants, the following inequality must hold:

$$
1-(1-p)^{N-k}+S(1-p)^{N-k}>1-(1-p)^{N} .
$$

If we solve inequality (A3) for $S$, we can show that this inequality holds if and only if

$$
S>1-(1-p)^{k}
$$

Next consider the maximum amount that these $k$ defendants would agree to pay in a settlement. As we have seen, the government can obtain the maximum amount through a Chicago auction. In the case of this settlement, each defendant would bid an amount $s$ high enough to make each indifferent between settling for $s$ and being one of the $N-k$ defendants litigating against

\footnotetext{
${ }^{58}$ See Chang \& Sigman, supra note 28, at 216, 234.
} 
the government after $k$ defendants have each settled for this amount $s$. Given that each settling defendant pays an equal amount in such a settlement, we know $s=S / k$. Therefore, each defendant would agree to the following settlement amount:

$$
\frac{S}{k}=\frac{(1-S)\left[1-(1-p)^{N-k}\right]}{N-k} .
$$

Multiplying both sides of equation (A5) by $(N-k) k$, then solving for $S$, yields the following settlement:

$$
S=\frac{\left[1-(1-p)^{N-k}\right] k}{N-k(1-p)^{N-k}}
$$

We can show that this amount is less than the settlement amount in inequality (A4) that the government would require to make this settlement worthwhile:

$$
\frac{\left[1-(1-p)^{N-k}\right] k}{N-k(1-p)^{N-k}}<1-(1-p)^{k}
$$

By multiplying both sides of inequality (A7) by $N-k(1-p)^{N-k}$, then simplifying, we can show that this inequality is true if and only if:

$$
\frac{1-(1-p)^{N}}{N}<\frac{1-(1-p)^{k}}{k}
$$

which we know must be true for any $k<N$, because a defendant only gains by having more defendants added to the case.

A defendant gains from the addition of more defendants, which would reduce that defendant's expected share of liability in the event that a court finds the defendant liable. To prove inequality (A8) formally, we can take the derivative of the left-hand side of this inequality with respect to $N$ and show that this derivative is negative if and only if

$$
[1-N \ln (1-p)](1-p)^{N}<1 .
$$


Note that the left-hand side of inequality (A9) equals one if $p=0$, so if this side decreases in $p$, then this inequality is true. To prove inequality (A9) holds, we can take the derivative of the left-hand side with respect to $p$ and show that this derivative is negative if and only if

$$
N^{2} \ln (1-p)<0,
$$

which is true for any $N>0$ and $0<p<1$.

Thus, we have established the proposition that the government would never find it in its interest to enter a single settlement and litigate against the nonsettling defendants. We can use this proposition to show that the government would never enter a series of settlements either. First, recall that we have shown that the government would always litigate against two defendants. We can extend this result to the case of three defendants using our proposition, which implies that the government could not gain by settling with the third defendant nor by settling with two of the three defendants. With this result, we can then use our proposition to extend the result to the case of four defendants, as so forth, so that the result must hold for any N. Q.E.D. 


\section{REFERENCES}

Acton, Jan Paul, and Lloyd S. Dixon, Superfund and Transaction Costs: The Experiences of Insurers and Very Large Industrial Firms (Santa Monica, CA: RAND, 1992).

Bartsch, Charles, and Rachel Deane, Brownfields State of The States: An End-of-Session Review of Initiatives and Program Impacts in the 50 States (Washington, DC: Northeast-Midwest Institute, $5^{\text {th }}$ ed. 2002).

Boyd, James, Winston Harrington, and Molly K. Macauley, "The Effects of Environmental Liability on Industrial Real Estate Development," Journal of Real Estate Finance and Economics 12 (1996), 37-58.

Chang, Howard F., and Hilary Sigman, "Incentives to Settle under Joint and Several Liability: An Empirical Analysis of Superfund Litigation," Journal of Legal Studies 29 (2000), 205-236.

Clarke, Chris, Update Comparative Legal Study on Environmental Liability (Brussels, Belgium: European Commission, 2001).

Dixon, Lloyd S., "The Transaction Costs Generated by Superfund's Liability Approach," in Richard L. Revesz \& Richard B. Stewart (eds.), Analyzing Superfund: Economics, Science, and Law (Washington, DC: Resources for the Future, 1995), 171-185.

Dixon, Lloyd S., Deborah S. Drezner, and James K. Hammitt, Superfund: Private-Sector Expenditures and Transaction Costs (Santa Monica, CA: RAND, 1993).

Donohue, John J., III, "The Effect of Joint and Several Liability on the Settlement Rate - Mathematical Symmetries and Metaissues about Rational Litigant Behavior: Comment on Kornhauser and Revesz," Journal of Legal Studies 23 (1994), 543-558.

Easterbrook, Frank H., William M. Landes, and Richard A. Posner, "Contribution among Antitrust Defendants: A Legal and Economic Analysis," Journal of Law and Economics 23 (1980), 331-370. 
Environmental Law Institute, An Analysis of State Superfund Programs: 50State Study, 2001 Update (Washington, DC: Environmental Law Institute, 2002).

Geltman, Elizabeth Glass, "Recycling Land: Encouraging the Redevelopment of Contaminated Property," Natural Resources \& Environment 10 (Spring 1996), 3-10.

Kahan, Marcel, "The Incentive Effects of Settlements under Joint and Several Liability," International Review of Law and Economics 16 (1996), 389-395.

Klerman, Daniel, "Settling Multidefendant Lawsuits: The Advantage of Conditional Setoff Rules," Journal of Legal Studies 25 (1996), 445-462.

Kornhauser, Lewis A., and Richard L. Revesz, "Multidefendant Settlements: The Impact of Joint and Several Liability," Journal of Legal Studies 23 (1994), 41-76.

Kornhauser, Lewis A., and Richard L. Revesz, "Evaluating the Effects of Alternative Superfund Liability Rules," in Richard L. Revesz \& Richard B. Stewart (eds.), Analyzing Superfund: Economics, Science, and Law (Washington, DC: Resources for the Future, 1995), 115-144.

Noah, Timothy, "EPA Plans Rules to Limit Liability of Superfund Sites," Wall Street Journal (Jan. 26, 1995), A5.

Office of Enforcement and Compliance Assurance, U.S. Environmental Protection Agency, Policy Toward Owners of Property Containing Contaminated Aquifers (Washington, DC: U.S. Environmental Protection Agency, 1995).

Percival, Robert V., Christopher H. Schroeder, Alan S. Miller, and James P. Leape, Environmental Regulation: Law, Science, and Policy (New York, NY: Aspen Publishers, $4^{\text {th }}$ ed. 2003).

Plater, Zygmunt J.B., Robert H. Abrams, William Goldfarb, Robert L. Graham, Lisa Heinzerling, and David A. Wirth, Environmental Law and 
Policy: Nature, Law, and Society (New York, NY: Aspen Publishers, 3d ed. 2004).

Polinsky, A. Mitchell, and Daniel L. Rubinfeld, "The Deterrent Effects of Settlements and Trials," International Review of Law and Economics 8 (1988), 109-116.

Polinsky, A. Mitchell, and Steven Shavell, "Contribution and Claim Reduction among Antitrust Defendants: An Economic Analysis," Stanford Law Review 33 (1981), 447-471.

Reisch, Mark, Resources, Science, and Industry Division, Congressional Research Service, Brownfields and Superfund Issues in the $108^{\text {th }}$ Congress (Washington, DC: Congressional Research Service, 2004).

Segerson, Kathleen, "Liability Transfers: An Economic Assessment of Buyer and Lender Liability," Journal of Environmental Economics and Management 25 (1993), S-46 to S-63.

Segerson, Kathleen, "Property Transfers and Environmental Pollution: Incentive Effects of Alternative Policies," Land Economics 70 (1994), 261272.

Sigman, Hilary, "Environmental Liability and Redevelopment of Old Industrial Land," unpublished manuscript, Rutgers University (2006).

Spence, David B., "Imposing Individual Liability as a Legislative Policy Choice: Holmesian 'Intuitions' and Superfund Reform," Northwestern University Law Review 93 (1999), 389-452.

Spier, Kathryn E., "A Note on Joint and Several Liability: Insolvency, Settlement, and Incentives," Journal of Legal Studies 23 (1994), 559-568.

Tietenberg, Tom H., "Indivisible Toxic Torts: The Economics of Joint and Several Liability," Land Economics 65 (1989), 305-319. 
U.S. Conference of Mayors, Recycling America's Land: A National Report on Brownfields Redevelopment 4 (Washington, DC: U.S. Conference of Mayors, 2003).

Wernstedt, Kris, Lauren Heberle, Anna Alberini, and Peter Meyer, "The Brownfields Phenomenon: Much Ado about Something or the Timing of the Shrewd?," Discussion Paper No. 04-46, Resources for the Future (2004).

Wernstedt, Kris, Peter B. Meyer, and Anna Alberini, "Attracting Private Investment to Contaminated Properties: The Value of Public Interventions," Journal of Policy Analysis and Management 25 (2006), 347-369. 